\title{
Sosialisasi Kecerdasan dalam Memaknai Pesan Media Era Digital: Fakta Versus Hoaks di Pesantren Nurul Falah Meulaboh
}

\author{
Desi Maulida ${ }^{1}$, Irma Juraida ${ }^{2}$, Rahmah Husna Yana ${ }^{3}$, Arfriani Maifizar ${ }^{4}$ \\ 1 Jurusan Ilmu Komunikasi, Universitas Teuku Umar \\ Email: desimaulida@utu.ac.id \\ 2,3,4Jurusan Sosiologi, Universitas Teuku Umar \\ Email: irmajuraida@utu.ac.id \\ Email: rahmahusnayana@utu.ac.id \\ Email: arfriani.maifizar@utu.ac.id
}

Submitted: 02 Desember 2019 Revised: 17 Desember 2019 Accepted: 21 Desember 2019

\begin{abstract}
Education about the use of media especially digital media is now important to be given to all levels of society, especially the younger generation, so that this socialization is aimed at students at the Nurul Falah Islamic Boarding School Dayah Inti Meulaboh. The method of socialization used was the presentation of theories about social media including how to distinguish between facts and hoaks. The socialization took place interactively, there was a discussion room so as to facilitate the speaker in achieving the objectives of the socialization.. The results of socialization show that initially the students did not really understand related to how to filter information to distinguish hoaks and facts. That is because, they are less intense using hand phone, so that students can easily trust information obtained from the internet, especially social media. With this socialization, students have been theoretically equipped about how to filter information and distinguish between hoaks and facts, and are able to stimulate students to be more observant and critical in responding to information.
\end{abstract}

Keywords: Socialization, Social Media, Hoaks, Fact

\begin{abstract}
Abstrak
Edukasi pemanfaatan media khusunya media digital saat ini menjadi hal penting untuk diberikan kepada seluruh lapisan masyarakat, terutama generasi muda, sehingga pengabdian ini menyasar kepada para santri di Pesantren Nurul Falah Dayah Inti Meulaboh. Metode sosialisasi yang digunakan adalah pemaparan materi mengenai media social termasuk bagaimana cara membedakan fakta dengan hoaks. Sosialisasi berlangsung secara interaktif, tersedianya ruang diskusi sehingga memudahkan pemateri dalam mencapai tujuan sosialisasi.. Hasil pengabdian menunjukkan bahwa awalnya para santri tidak begitu memahami terkait dengan cara menyaring informasi untuk membedakan hoak dan fakta. Hal itu dikarenakan, kurang intensnya mereka menggunakan handphone, sehingga para santri bisa dengan mudahnya mempercayai begitu saja informasi yang didapatkan dari media internet, khususnya media sosial. Dengan dilakukannya sosialisasi ini, para santri sudah terbekali secara teoritis mengenai cara menyaring informasi dan membedakan antara hoaks dan fakta, serta mampu menstimulasi para santri agar lebih jeli dan kritis dalam menanggapi sebuah informasi.
\end{abstract}

Kata Kunci: Sosialisasi, Media Sosial, Hoaks, Fakta

\section{PENDAHULUAN}

Kemajuan teknologi Kemajuan teknologi saat ini turut mengubah cara orang dalam memperoleh informasi terutama melalui media digital (internet). Kebanyakan masyarakat Indonesia menjadikan media internet sebagai referensi 
utama mendapatkan informasi dan berita karena sifatnya yang tidak terbatas ruang dan waktu. informasi dapat diakses kapanpun dan dimanapun selama masih dalam konektivitas jaringan internet. Informasi yang diperoleh juga beragam dan mampu menyentuh ranah secara global/dunia. Ragamnya informasi yang dihadirkan melalui media digital secara tidak langsung mengharuskan secara aktif dan solutif dalam memilih informasi(Silverman, 2015)

Kehadiran internet sedikit banyak membantu para pengguna dalam memperoleh berbagai informasi karena fungsinya sebagai sumber ide, sumber informasi, tukar menukar data, dan masih banyak lagi. Namun perkembangan Teknologi Informasi dan Komunikasi (TIK) yang terjadi saat ini menyebabkan terjadinya keberlimpahan informasi (information overload) sehingga diperlukan strategi dalam melakukan penelusuran atau pencarian informasi melalui internet.

Saat ini, internet merupakan salah satu sumber belajar bagi pelajar, karena dengan menggunakan internet pelajar dapat mengakses informasiinformasi secara cepat dan mudah.
Bahkan berbagai sumber informasi dari berbagai media dapat dimodifikasi melalui internet. Namun, belakangan ini perkembangan teknologi yang semakin modern dan canggih ini tidak hanya memberikan manfaat bagi penggunanya, namun juga menimbulkan pengaruh yang negatif bagi penggunanya, terutama bagi kalangan pelajar yang terkadang belum mampu menyaring setiap informasi yang diperoleh. Artinya, internet dapat mempengaruhi sisi baik dan sisi jelek dari pengguna internet terutama dikalangan pelajar terlebih dengan hadirnya media sosial.

Berdasarkan data yang dirilis resmi oleh Asosiasi Penyelenggara Jasa Internet Indonesia (APJII) pengguna internet terbanyak ada pada usia 15 hingga 19 tahun. Sementara itu, pengguna terbanyak kedua berada pada umur 20 hingga 24 tahun. Anak-anak berumur 5 hingga 9 tahun pun juga menggunakan internet, bahkan mencapai 25,2 persen dari keseluruh sampel yang berada pada umur tersebut (AJJI, 2019). Media sosial menjadi media yang paling banyak diakses oleh para remaja. Dampak dari menjamurnya media sosial sebagai bagian dari media baru adalah kemudahan untuk mengakses informasi dan 
kemudahan untuk memberikan pengaruh negatif bagi penggunanya (Nasrullah, 2015). Dennis Mcquail, menjelaskan bahwa ciri-ciri media baru adalah 1.) interkonektivitas, yaitu adanya akses terhadap khalayak individu, dan 2.) interaktivitas, yaitu kegunaan beragam untuk berbagai macam jenis manusia. Interkonektivitas berarti adanya hubungan antara satu perangkat dengan perangkat yang lain, sementara interaktivitas berarti di dalam media baru memiliki peluang untuk melakukan interaksi antara pengguna dengan pengguna yang lain. Ciri-ciri ini kemudian juga memungkinkan untuk memperluas peluang penyebaran informasi bohong atau hoaks di tengah-tengah para pengguna media sosial di Indonesia. Hoaks dipahami sebagai rangkaian informasi yang memang sengaja disesatkan, namun 'dijual sebagai kebenaran.

Saat ini, masyarakat pengguna internet di Indonesia cenderung suka menyebarkan informasi ke orang lain tanpa lebih dahulu memeriksa kebenarannya. Seakan ingin jadi orang yang pertama menyebar informasi, mencari sensasi, sampai berlomba-lomba menikmati kesenangan dalam kebohongan. Kehadiran internet seperti media sosial mengakibatkan penyebaran hoaks saat ini menjadi lebih cepat dan berkembang.. Dengan media sosial, penyebar hoaks merasa aman karena tidak berhadapan langsung dengan pihak lain yang dijadikan sasaran hoaks dan disajikan seolah-olah sebagai serangkaian fakta (Mansyur, 2016)

Generasi muda berperan sangat penting dalam perkembangan tekhnologi dan media sosial. Sehingga diperlukan peran pemuda sebagai agen pencegahan informasi/berita hoaks. Hal ini dikarenakan kehidupan anak muda yang seakan tidak pernah bisa dilepaskan dari pengaruh media sosial dan sangat potensial untuk dipengaruhi oleh berita hoaks. Terlebih, media sosial saat ini menjelma sebagai sarana yang paling modern untuk menyampaikan sebuah pemikiran dan opini, media sosial ibarat hutan belantara dan setiap orang yang tidak berhati-hati akan terjebak di dalamnya.

Permasalahan ini tentu dirasakan juga oleh sebahagian besar pelajar yang mungkin baru menggunakan handphone dan jaringan internet sebagai referensi dari setiap informasi yang diperlukan, termasuk murid-murid sekolah menengah Pertama (SMP) pada Pesantren Nurul Falah Dayah Inti Meulaboh Meulaboh, yang 
notabenenya adalah santri dan santriwati yang tidak sepenuh waktu menggunakan internet dikarenakan aturan sekolah yang tidak membenarkan membawa handphone ketika berada di lingkungan sekolah. Hal ini kemudian dikhawatirkan akan menjadi sebuah tantangan baru mengenai bagaimana menyaring informasi dengan dibekali pengetahuan awal tentang kebijakan dalam penggunaan internet, sehingga tidak akan mudah percaya terkait dengan ragamnya informasi yang nanti didapatka. Kecerdasan dalam memaknai hoaks dan fakta harus ditanamkan sedari awal untuk meminimalisir pengadopsian dan penyebaran berita hoaks kepada orang lain secara masif dan terusmenerus. Pemahaman pemanfaatan media sosial secara baik dan cerdas dianggap penting untuk menumbuhkembangkan potensi berliterasi santri, untuk selanjutnya dapat diarahkan secara tepat dan bermanfaat.

\section{METODE PELAKSANAAN}

Materi yang diberikan dalam sosialisasi pemanfaatan media ini bertajuk kecerdasan dalam memaknai pesan media digital: Fakta versus Hoaks. Sosialisasi ini dilaksanakan pada hari Senin tanggal 18 November 2019 bertempat di Gedung Pesantren Nurul Falah Dayah Inti Meulaboh, dimulai pada Pukul 15.00 sampai dengan selesai. Sosialisasi ini bertujuan untuk memberikan pemahaman kepada para santri khususnya santriwati di lingkup Pesantren Nurul Falah Dayah Inti Meulaboh agar aktif dalam memerangi hoaks dan tidak mudah mempercayai atau bahkan mendistribusikan berita/informasi hoaks kepada orang lain. Sosialisasi ini merupakan sosialisasi terkait media pertama kali yang pernah diselenggarakan di Pesantren Nurul Falah Dayah Inti Meulaboh.

Pemaparan materi yang disampaikan oleh pemateri menekankan pada bagaimana peran kaum muda atau milenial dalam memerangi hoaks, yang dimulai dengan pengenalan media-media sosial yang dianggap lebih berkompeten menghadirkan hoaks sampai dengan menawarkan solusi terbaik dalam menyikap hal tersebut. Pada saat berlangsungnya sosialisasi, mampu menciptakan antusiasme dari para santriwati dalam merespons materi yang diberikan. Hal itu dikarenakan hamper keseluruhan dari para santriwati yang hadir, merupakan penikmat media sosial, baik yang digunakan untuk hiburan maupun sebagai referensi dalam mencari 
informasi atau membuat tugas sekolah.

Sosialisasi ini dianggap penting dilakukan, mengingat hoaks saat ini sudah merajalela dan tidak terkontrol, sehingga terkadang menimbulkan kecemasan dan kericuhan di masyarakat terkait dengan informasi bohong yang disampaikan dan diolah seakanakan bernilai fakta sehingga memungkinkan masyarakat untuk mempercayai dan mengadopsi secara mentah-mentah terkait dengan informasi yang didapat. Kegiatan tersebut mempunyai harapan agar pembelajaran mengenai pemanfaatan media akan terus berlanjut di Pesantren Nurul Falah Dayah Inti Meulaboh, mengingat keterbatasan akses informasi melaui hand phone (HP) sangat jarang dilakukan mengingat aturan yang tidak membenarkan membawa HP saat berada di lingkungan sekolah, sehingga ditakutkan pada saat para santriwati menggunakan HP di rumah atau di luar sekolah akan secara sertamerta mempercayai semua yang dihadirkan di media tanpa menyaring terlebih dahulu.

\section{HASIL DAN PEMBAHASAN}

Kebijakan pemanfaatan media saat ini khususnya media digital menjadi hal penting untuk dibahas dan diaplikasikan dalam kehidupan sehari-hari, mengingat media saat ini menjadi sumber referensi utama bagi sebagian besar masyarakat Indonesia, khususnya kaum muda dalam memenuhi kebutuhan informasi. Kebijakan dalam memanfaatkan media selain untuk memenuhi keutuhan informasi secara beragam, juga bertujuan untuk mengetahui nilai dari sebuah informasi maupun berita, apakah informasi tergolong hoaks atau fakta yang bisa dipercaya. Oleh karena itu, sosialisasi terkait dengan kecerdasan dalam memaknai hoaks dan fakta menjadi landasan awal untuk diberikan kepada para generasi muda agar pesan hoaks dapat ditepis dan ditolak secara tegas.

Pada kegiatan sosialisasi yang telah dilakukan, sebagian besar para santriwati mengaku sangat sulit untuk membedakan antara hoaks dan fakta. Kelihaian para penyebar informasi dalam mengemas berita kerap kali membuat para santriwati terkecoh dan terjebak sehingga terkadang membuat mereka mempercayai suatu informasi menjadi sebuah informasi bernilai fakta. Pengetahuan awal mengenai cara untuk membedakan informasi hoaks dan fakta dianggap masih sangat minim. Terhadap kekurangan pengetahuan seperti itu, Sosialisasi ini memberikan pemahaman kepada generasi muda 
khususnya satriwati lingkup Pesantren Nurul Falah Dayah Inti Meulaboh tentang bagaimana seharusnya menyaring informasi secara aktif dan kritis sehingga menghindari dari adopsi hoaks.

Hoaks dipahami sebagai berita palsu atau berita bohong yang sengaja dibuat untuk menciptakan kecemasan, kebencian, kecurigaan atau ketidakpercayaan hingga permusuhan, biasanya informasi hoaks sumber berita tidak jelas. Hoaks di media sosial biasanya menyangkut pemberitaan media yang tidak terverifikasi, tidak berimbang, dan cenderung menyudutkan pihak tertentu (Nares, 1822). Sedangkan fakta merupakan sesuatu yang apa adanya terjadi. Secara umum, fakta dipahami sebagai hal yang sebenarnya, baik karena mereka telah mengalami kenyataankenyataan dari dekat maupun karena mereka dianggap telah melaporkan pengalaman orang lain yang sesungguhnya. Hoaks dan fakta merupakan dua hal yang berbeda dan berbanding terbalik jika dilihat dari nilai keakuratan dan kebenaran informasi. Kurangnya pengetahuan awal menjadi alasan utama para santriwati kesulitan dalam membedakan antara hoaks dan fakta yang berseliweran di media sosial.
Media sosial telah menjadi jalan utama dengan pengguna terbanyak dalam mengkonsumsi serta membagikan atau menyebarluaskan berita, baik itu mengenai kehidupannya atau mengenai kejadian-kejadian yang ada di dunia secara luas(Hill \& Lashmar, 2013)

Media sosial menjadi wadah penyumbang informasi terbesar saat ini. Berdasarkan pengakuan dari sebagian besar santriwati, mereka biasanya melihat dan mendapatkan informasi dari media sosial, seperti facebook, twitter, maupun instragram. Pemanfaatan media social terkadang kerap kali menjebak para santriwati dengan berita-berita yang apik dengan judul yang menarik perhatian. Namun, terkadang ada beberapa informasi yang sering kali tidak berbanding lurus dengan judul berita. Santriwati mengaku, pihak penyebar informasi sengaja membuat judul sedemikian menarik untuk menarik perhatian mereka, sehingga mengundang rasa penasaran untuk dibaca.

Terkait dengan kurangnya pengetahuan awal mengenai perbedaan berita hoaks dan fakta, maka materi yang diberikan selanjutnya adalah berupa solusi dari permasalahan yang diamati. Pemateri memberikan materi secara menyeluruh, baik secara teoritis sampai praktik cara melaporkan 
hoaks. Gambar 1 berikut pada saat

memperhatikan materi yang menjelaskan materi dan terlihat betapa seriusnya para santri disampaikan oleh pemateri saat sosialisasi.

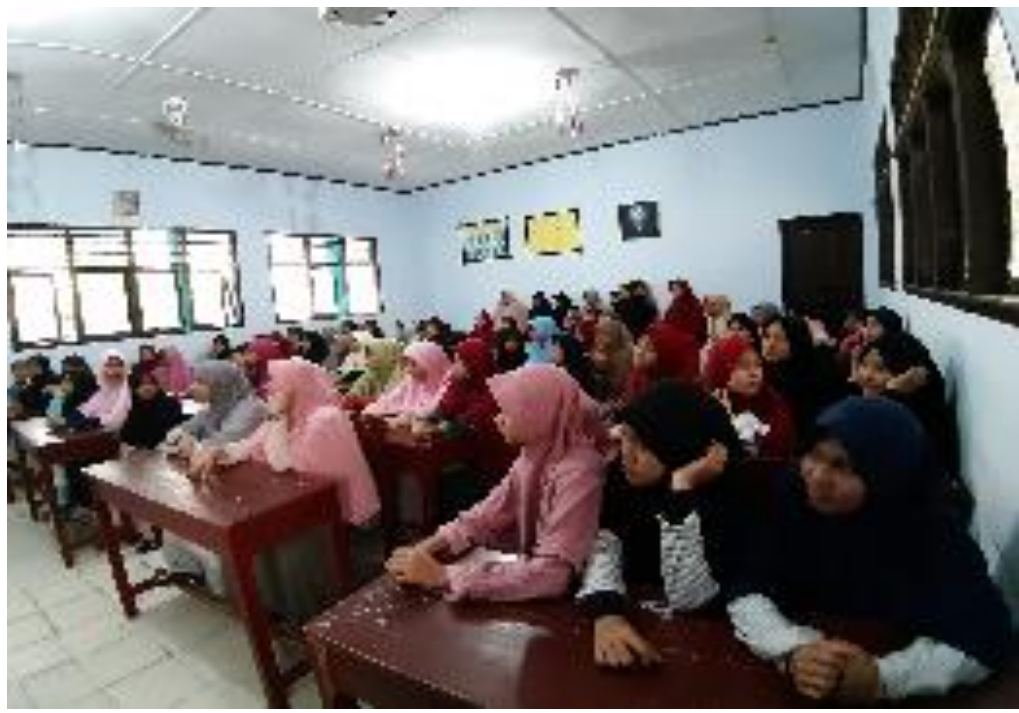

Gambar 1. Keseriusan para santri

mendengarkan materi saat sosialisasi

Diantara solusi dalam menyaring dan membedakan hoaks versus fakta, pertama memastikan berita yang dibaca tidak memiliki kalimat-kalimat yang janggal, seolah persuasif dan memaksa seperti: "Sebarkanlah!", "Viralkanlah!", dan sejenisnya. Artikel penuh huruf besar dan tanda seru pun disinyalir mengandung informasi hoaks. Tidak hanya itu, artikel atau berita hoaks biasanya merujuk pada waktu kejadian yang kurang jelas bahkan meragukan, seperti "kemarin", "dua hari yang lalu", "seminggu yang lalu" tanpa dibubuhkan tanggal dan hari yang jelas peristiwa tersebut terjadi.
Kedua, memverifikasi sumber dan konten berita dengan mencarinya di mesin pencarian, misalnya Google. Hal ini dilakukan dengan mencari tema berita yang sejenis secara spesifik dengan kata hoaks di belakangnya. Ketiga, memastikan sumber foto yang diunggah di artikel atau berita terkait. Kita dapat mengecek kembali apakah foto tersebut asli atau tidak. Kita hanya perlu memanfaatkan tool milik Google, yaitu Google Image. Langkah awal, simpan foto berita yang diduga berita hoaks, screenshoot pada artikel tersebut, lalu masuk pada laman Google Images. Kemudian, sisipkan foto yang kita simpan tadi di laman 
Google Images. Selanjutnya Drag foto tersebut ke kolom pencarian.

Keempat, mengecek konten hoaks dengan aplikasi khusus bernama Hoaks Analyzer dan Copyscape. Aplikasi tersebut mampu membantu dalam verifikasi berita, baik fakta maupun hoaks dengan melakukan cross check pada hasil pencarian teratas di semua mesin pencarian dan artikel yang terhubung dengan keyword atau kata kunci artikel terkait.
Pemberian materi tersebut berlangsung secara interaktif, serta diberikan kesempatan kepada santriwati untuk memberikan tanggapan dan pertanyaan jika ada hal yang sulit dipahami seperti yang terlihat pada Gambar 2, dimana salah satu santri menanyakan perihal tips yang diberikan oleh pemateri yang dirasa masih belum dipahami secara jelas terkait dengan cara penggunaannya.

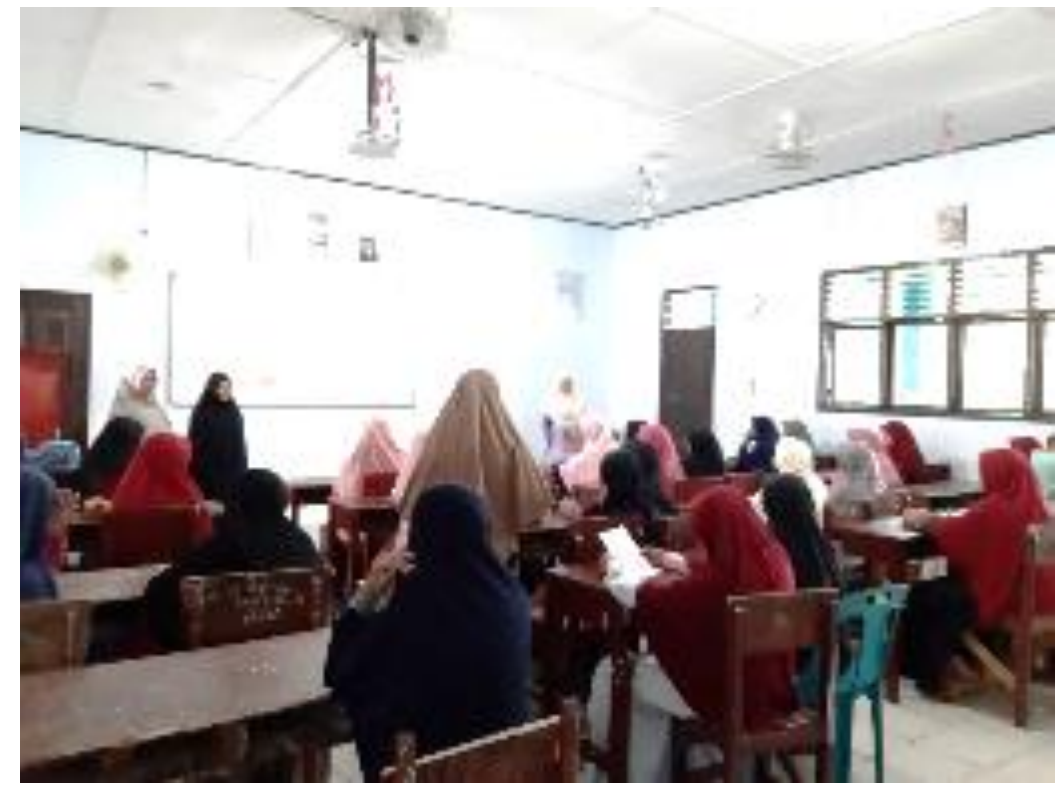

Gambar 2. Santri mengajukan pertanyaan kepada pemateri

Diantara keempat tips diatas, tips yang dianggap paling sulit untuk diaplikasikan adalah tips ketiga, yaitu memastikan foto yang diunggah penyebar berita apakah asli atau hoaks. Khusus membahas tips ketiga ini, dibuka ruang diskusi khusus yang terdiri dari 4 kelompok yang diketuai oleh 4 dosen pada masing-masing kelompok, sehingga komunikasi menjadi lebih intens sehingga mampu memberikan pemahaman secara mendalam.

Selanjutnya, sosialisasi ini diharapkan mampu memberikan kontribusi kepada santriwati dalam memaknai berita hoaks dan fakta, sehingga nantinya akan lebih 
mudah membedakan hoaks dengan fakta. Hal itu dikarenakan, di bangku sekolah dirasa tidak cukup memberikan ruang dan waktu bagi mereka dalam mempelajari hal ini, terlebih adanya aturan sekolah yang tidak membenarkan para santri maupun santriwati membawa hand phone di lingkungan sekolah. Sosialisasi ini setidaknya dapat membantu terkait pengetahuan awal dalam pemanfaatan media sosial yang tidak boleh sembarangan dan harus jeli dalam menyaring berita, sehingga tidak terjebak dengan berita palsu, sehingga ditakutkan akan diteruskan kepada teman yang lain tanpa mengecek kebenaran berita terlebih dahulu. Berikut pada Gambar 3 foto bersama dengan para santriwati setelah selesai memberikan materi.

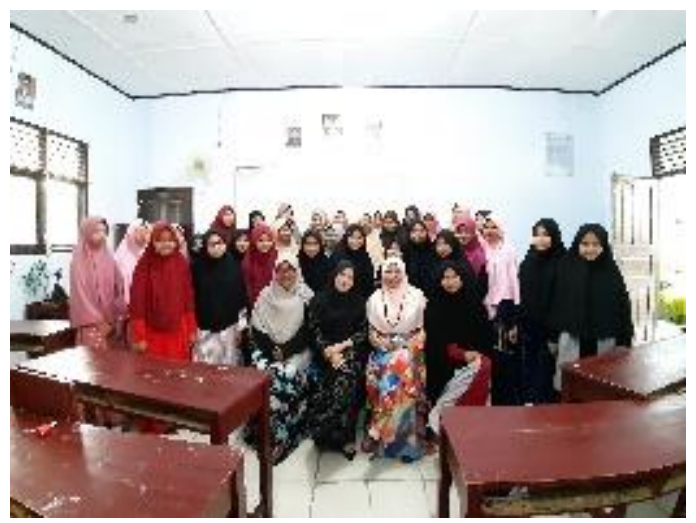

Gambar 3. Foto Bersama para Santri dengan Pemateri

\section{PENUTUP}

Hasil yang dicapai melalui kegiatan pengabdian masyarakat ini diantara, pertama para santri terbekali dengan pengetahuan terkait dengan pemanfaatan media sosial secara bijak dan cerdas sehingga dapat memudahkan mereka dalam membedakan kedunya fakta dengan hoaks. Kedua, para santri menjadi memahami cara-cara teoritis untuk membedakan fakta dan hoaks. Ketiga, para santri distimulasi agar lebih tanggap, jeli dan kritis dalam menanggapi sebuah informasi.

Adapun saran yang dapat disampaikan berupa pemanfaatan media sosial secara cerdas di kalangan khususnya generasi muda dapat ditingkatkan dengan mendorong kalangan para siswa atau santri untuk lebih gencar berliterasi dengan menggunakan media secara bijak, melalui suatu pelatihan dan sosialisasi. Ke depan, dapat dilakukan sosialisasi berkelanjutan sebagai bekal pengetahuan yang memadai sehingga diharapkan para generasi muda akan lebih memahami, menyaring dan menyeleksi informasi-informasi yang dihadirkan oleh media.

\section{DAFTAR PUSTAKA}

AJJI. (2019). Data Pengguna Internet di Indonesia. Jakarta.

Hill, S., \& Lashmar, P. (2013). Online Journalism: The Essential Guide. New York: SAGE Publications. 
Mansyur, U. (2016). Bahasa Indonesia dalam Belitan Media Sosial: Dari Cabe-cabean Hingga Tafsir Al-Maidah 51. In Prosiding Seminar Nasional $\mathcal{E}$ Dialog Kebangsaan dalam Rangka Bulan Bahasa (pp. 145-155). Makassar: Fakultas Ilmu Budaya Universitas Hasanuddin.

Nares, R. (1822). A Glossary: Or, Collection of Words, Phrases, Names, Allusions to Customs. London.

Nasrullah, R. (2015). Media Sosial Perspektif Komunikasi, Budaya dan Sosioteknologi. Bandung: SimbiosaRekatama Media.

Silverman, C. (2015). Lies, Damn Lies and Viral Co\|ntent. Columbia: Journalism Review. 